\title{
FOREST TEAMS AS AN ALTERNATIVE SERVICE OF THE MENNONITES IN THE RUSSIAN EMPIRE UNTIL 1914
}

\author{
Ol'ga V. Erokhina \\ Moscow Pedagogical State University, Moscow, Russian Federation
}

\begin{abstract}
Introduction. In the Russian Empire, the Mennonites, like German colonists, had numerous privileges, including they were not drafted for military service. This privilege was abolished after the Edict of 1874 was issued. However, they could not serve in the army due to their religious views. Methods and materials. The source base of the topic under study includes mainly written materials. Therefore, to show how the "military service" of the Mennonites was organized in forest teams, we used materials from the archives of the Russian State Historical Archive $(387,1246,1282,1292)$. Based on the documentary material with the use of the historicalsystemic method, we restored the chronology of the negotiation process between the authorities and the Mennonites on the introduction of alternative service. The paper reveals the terms of the agreement between the Mennonites and the Russian authorities. The Mennonites were forced to agree with these conditions in order not to take up arms. Analysis and Results. Based on the archival material, we found that the reaction from the Mennonites was immediate. On the one hand, they tried to establish a dialogue with the authorities on the resolution of an alternative civilian service, and on the other hand, many began to migrate to America. As a result, the Mennonites succeeded in obtaining the right to serve in forest teams and to submit to the Ministry of State Property. It was revealed that the subordination to the civil department instead of the military one changed their position from unranked soldiers to obligated workers. Therefore, they received monetary reward for their work. It was established that the Mennonite communities built and equipped barracks at their own expense; bought clothing and food; delivered the Mennonites to the place of service; paid rent for the ground areas allocated for agricultural needs to forest teams. A working day of obligated workers was strictly regulated and did not differ from the army one in fact. In the first half of the day, they always dealt with clearing and improvement of forests, and mainly with their protection. In their spare time the Mennonites played musical instruments and read books. In addition, they were necessarily taught reading and writing in Russian. Educational supplies were purchased at the expense of the team. Despite many difficulties in organizing and maintaining forest teams, many of the Mennonites performed their duties conscientiously and were encouraged by the ministry for good service more than once.
\end{abstract}

Key words: colonists, Mennonites, military service, alternative service, Russian Empire.

Citation. Erokhina O.V. Forest Teams as an Alternative Service of the Mennonites in the Russian Empire Until 1914. Vestnik Volgogradskogo gosudarstvennogo universiteta. Seriya 4. Istoriya. Regionovedenie. Mezhdunarodnye otnosheniya [Science Journal of Volgograd State University. History. Area Studies. International Relations], 2019, vol. 24, no. 3, pp. 68-78. (in Russian). DOI: https://doi.org/10.15688/jvolsu4.2019.3.6

\section{ЛЕСНЫЕ КОМАНДЫ - АЛЬТЕРНАТИВНАЯ СЛУЖБА МЕННОНИТОВ В РОССИЙСКОЙ ИМПЕРИИ ДО 1914 ГОДА}

\section{Ольга Викторовна Ерохина}

Московский педагогический государственный университет, г. Москва, Российская Федерация

Аннотация. В Российской империи меннониты, как и немецкие колонисты, имели многочисленные привилегии, в том числе они не призывались на военную службу. После издания Указа от 1874 г. эта льгота была им отменена. Однако из-за религиозных взглядов они не могли служить в армии. На основе архивного 
материала нами установлено, что реакция со стороны меннонитов последовала незамедлительно. С одной стороны, они пытались наладить диалог с властью о разрешении альтернативной гражданской службы, а с другой - многие стали эмигрировать в Америку. В результате меннонитам удалось добиться права служить в лесных командах и подчиняться Министерству государственных имуществ. Выявлено, что подчинение не военному ведомству, а гражданскому изменило их положение рядового на обязанного рабочего, поэтому за свой труд они получали денежное вознаграждение. Установлено, что меннонитские общины за свой счет строили и оборудовали казармы, покупали обмундирование и продовольствие, доставляли меннонитов до места службы, оплачивали аренду земельных участков, отведенных под сельскохозяйственные нужды лесным командам. Рабочий день обязанных рабочих был строго регламентирован и фактически не отличался от армейского. В первой половине дня они всегда занимались расчисткой и благоустройством лесов, а главное, их охраной. В свободное время меннониты играли на музыкальных инструментах, читали книги. Кроме того, их обязательно обучали чтению и письму на русском языке. Учебные принадлежности приобретались на средства команды. Несмотря на многочисленные трудности при организации и содержании лесных команд, многие из меннонитов добросовестно выполняли свои обязанности и неоднократно поощрялись министерством за хорошую службу.

Ключевые слова: колонисты, меннониты, воинская повинность, альтернативная служба, Российская империя.

Цитирование. Ерохина О. В. Лесные команды - альтернативная служба меннонитов в Российской империи до 1914 года // Вестник Волгоградского государственного университета. Серия 4, История. Регионоведение. Международные отношения. - 2019. - Т. 24, № 3. - С. 68-78. - DOI: https://doi.org/10.15688/jvolsu4.2019.3.6

Введение. С 1993 г. граждане Российской Федерации по религиозным убеждениям, согласно Конституции, имеют право вместо военной службы проходить альтернативную гражданскую. Однако до 2002 г. реализовать это право было фактически невозможно из-за неразработанности законодательной базы, но и сегодня существуют проблемы для тех, кто хотел бы воспользоваться правом альтернативной службы.

В связи с этим хотелось бы обратиться к историческому опыту Российской империи, изучение которого может оказаться полезным в современных реалиях. Впервые альтернативная служба в России была введена еще в середине 70-х гг. ХІХ в. для меннонитов, которые отказывались служить в армии из-за пацифистских убеждений. В результате властям пришлось вносить изменения в ст. 157 Устава о воинской повинности, вводя альтернативную службу для них - лесные команды, и называли их не солдатами, а обязанными рабочими.

Методы и материалы. Поражение в Крымской войне показало не только социально-экономическую, но и военную отсталость России от европейских держав. Это обстоятельство послужило толчком к началу проведения реформ. Военные преобразования, проведенные Д.А. Милютиным, способствовали созданию новой системы комплектования ар- мии - введению всеобщей воинской повинности. О разработке и проведении военных реформ периода правления Александра II написано довольно много работ, основанных на широком круге источников [4; 7; 8], однако альтернативная служба меннонитов в Российской империи почти не привлекала внимания дореволюционных и советских исследователей.

Первый труд, посвященный этой теме, был опубликован чиновником Министерства государственных имуществ С.Д. Бондарем в 1916 г. [2]. В нем небольшой раздел посвящен анализу организации внутренней жизни обязанных рабочих от меннонитов. Кроме того, автор обратил внимание на то, что в Западной Европе они отбывали воинскую повинность и не прикрывались верой.

Затем только в начале XXI в. появляются публикации по «военной службе» меннонитов $[6 ; 9 ; 25 ; 26]$. В этих работах исследователи анализировали правовые аспекты введения альтернативной службы и реакцию меннонитов на ее применение. Также была рассмотрена их служба в санитарных батальонах во время Первой мировой войны и противостояние насилию в годы Гражданской войны. Однако к недостаткам этих работ следует отнести ограниченное использование архивных материалов.

К сожалению, источниковая база исследуемой темы представлена преимуществен- 
но письменными материалами, поэтому, чтобы показать, как была организована «военная служба» меннонитов в лесных командах, мы использовали материалы фондов Российского государственного исторического архива (387, 1246, 1282, 1292). На основе документального материала с применением историко-системного метода нами восстановлена хронология процесса переговоров властей с меннонитами о введении альтернативной службы. Выявлены условия соглашения между меннонитами и российскими властями, на которые меннониты вынуждены были пойти, чтобы не брать в руки оружия.

Анализ. Меннониты переселились в Россию в конце 80-х гг. XVIII в. и им предоставлялись такие же привилегии, как ранее переселившимся колонистам на основании Манифеста Екатерины II от 1763 года. Наряду с многочисленными льготами и привилегиями они были освобождены от воинской повинности: «Поселившиеся в России иностранные, во все время пребывания своего ни в военную, ни же в гражданскую службу против воли их определены не будут... а буде кто пожелает самоизвольно вступить в военную службу в солдаты, такому дается при определении в полк 30 рублей в награждение сверх обыкновенного жалования» [16, с. 314-315]. После окончания Крымской войны Александром II проводится военная реформа, направленная на «преобразование устройства военных сил Империи на основании указаний современного опыта» $[15$, с. 1].

В ходе обсуждения военной реформы на заседаниях комиссии поднимался вопрос о привлечении немцев на военную службу. Полковник М.С. Максаковский считал, что колонисты, как «граждане Российского государства... должны быть в такой же степени заинтересованы в обеспечении его от опасности, как и прочие подданные» [11, с. 40]. Кроме того, на страницах газет и журналов предлагались различные схемы привлечения колонистов к службе, но все единодушно признавали, что «в государственных вопросах общество должно быть равноправным, без каких бы то ни было исключений» [26, с. 17].

Довольно сложным был вопрос о предоставлении особых условий службы меннонитам, придерживавшимся пацифистских убеждений. Они были противниками насилия и счи- тали, что «не должны в этом мире мстить кому-либо... брать в руки оружия во имя царства мира, обещанного в пророчествах» [25, с. 72]. С учетом этих религиозных особенностей было принято решение «распространить воинскую повинность на колонистов, освобождавшихся ранее от рекрутской повинности, однако... сохранить некоторые из льгот меннонитам» [7, с. 312].

Меннониты были единственными, кому законодательно воинскую повинность заменили на альтернативную гражданскую службу. Почему и как это произошло?

Меннониты испытывали постоянные притеснения со стороны европейских властей в силу особенностей религиозного вероучения. Например, крещение у меннонитов совершалось над взрослыми людьми, судебные тяжбы, присяга и воинская служба отрицались. Однако их отказ от несения военной службы в условиях, когда европейские властители нуждались в людских ресурсах для поддержания работы военной машины, приводил к настоящему конфликту с властями. Это вынуждало меннонитов переселяться в другие страны, чтобы сохранять религиозные убеждения.

Для меннонитов было обязательным соблюдение всех религиозных заповедей, в том числе и «не убий». Менно Симонс считал, что в качестве средства борьбы надо использовать только «меч духа» - Слово Божье, «даже если мы должны быть порваны на тысячу частей» [27, р. 98].

Желание сохранить веру и возможность получения значительных льгот способствовали переселению в 1789 г. прусских меннонитов из европейских государств в Российскую империю. Первой группе переселенцев в составе 228 семейств было предоставлено место под колонии в Екатеринославской губернии, где в районе Днепра были основаны Хортицкие компактные поселения. В $1793-$ 1796 гг. там же поместят вторую группу меннонитов численностью в 118 семейств. С 1804 г. приезжающих меннонитов станут селить на реке Молочная в Таврической губернии. В результате будет образовано 18 колоний. К 1860 г. в этом регионе будет образовано около 50 колоний [23, с. 9]. Процесс переселения меннонитов в Россию продолжался вплоть до 70-х гг. ХIX века. 
По переписи населения 1897 г. общее число меннонитов в России составляло 66564 человек. Большинство из них проживало в губерниях: Таврической - 25508 чел., Екатеринославской - 23922 чел., Херсонской - 5386 чел., Самарской - 4616 человек. К началу XX в. общины меннонитов образовали дочерние колонии в Новороссии, Кубани, Средней Азии, Кавказе и Сибири в районе Омска, Томска и на Алтае [3, с. 42].

Довольно льготноеположениеменнонитов продолжалось вплоть до начала реформ 1860 70-х годов. С их помощью правительство рассчитывало модернизировать российскую экономику. В ходе преобразований немцы потеряли свои многочисленные привилегии, в том числе и освобождение от воинской повинности. Еще в процессе разработки реформы меннониты раскололись на два лагеря.

В первом лагере оказались сторонники, готовые идти на компромисс с властями и выступавшие за оказание добровольной помощи в случае войны (выделение денежных средств, предоставление жилья и транспорта, медицинская помощь раненным) армейским частям страны. Во втором - противники не только личного несения военной службы, но и любой косвенной ее поддержки. Они в основном высказывались за эмиграцию.

Осенью 1871 г. уполномоченные меннонитов Таврической губернии подали ходатайство императрице Марии Федоровне во время пребывания ее в Крыму об отмене всесословной воинской повинности к меннонитам. Она передала его на рассмотрение генерал-губернатору Новороссии и Бессарабии П.Е. Коцебу.

В своем письме императрице и в Министерство внутренних дел тот написал, что если правительство желает удержать это трудолюбивое население, то надо освободить его от воинской повинности под каким-нибудь предлогом и заменить ее косвенным платежом. Кроме того, он предлагал назначать меннонитов «на служительские должности при госпиталях на юге России, мастеровыми и техниками в заведения Морского ведомства в Николаев и т. п.» [5, л. 1-2]. В октябре и ноябре 1872 г. аналогичные записки были поданы меннонитами на имя императора Александра II [18, л. 3-4].
Так как российское правительство молчало, то меннониты стали эмигрировать из страны. Власти сначала довольно спокойно отнеслись к этому, считая, что они пытаются оказать на них давление и вынудить пойти им на уступки. Однако численность эмигрировавших неуклонно росла, и это могло привести к дестабилизации экономики на юге России.

Из регионов стали приходить тревожные письма от губернаторов. Например, в марте 1873 г. губернатор Таврической губернии А.А. Кавелин писал: «...стремление их [меннонитов] к переселению в Америку вполне зависит от тех материальных и религиозных выгод, которые они надеются получить в Америке по удостоверению переселившихся туда своих собратий. Последние, описывая Америку житницею всех материальных благ и представляя возможность уклониться там от воинской повинности посредством найма за себя других лиц, до того возбудили умы меннонитов к переселению, что дарованная им льгота бессильна остановить движение по переселению» [13, л. 6 об].

Таврическому губернатору была дана телеграмма от МВД: «До приезда воздержитесь выдачею паспортов» $[5$, л. 13]. В результате в апреле 1874 г. для переговоров с меннонитами был послан генерал-адъютант Э.И. Тотлебен. Он объехал более 60 колоний Таврической и Екатеринославской губерний с губернаторами и жандармскими штаб-офицерами и два раза созывал депутатов до 300 человек для разъяснения, что личную воинскую повинность они будут нести без нарушения религии. В Министерство внутренних дел он сообщал: «Цель достигнута без расширения шестилетней льготы. Думаю, что решимость менонитов остаться в России за исключением продавших имущество чистосердечна» $[5$, л. 40$]$.

В результате 8 апреля 1875 г. Государственный совет внес изменения в статью 157 Устава о воинской повинности, освободив меннонитов от ношения оружия, но они должны были отбывать службу в мастерских морского ведомства, в пожарных командах и в особых подвижных командах лесного ведомства. Однако это положение не распространялось на тех, кто присоединился к секте или приехал в Россию после 1 января 1874 г. [14, c. 340]. Кроме того, решено предоставить мен- 
нонитам 6-летнюю отсрочку от воинской повинности, и до 1880 г. они имели возможность выйти из русского подданства и уехать из России. Вероятно, до сведения колонистов не были доведены окончательные условия прохождения ими военной службы или же боязнь нарушения этих условий со стороны правительства способствовала тому, что они продолжали эмигрировать из страны.

Губернатор Екатеринославской губернии Н.А. Дурново считал, что даруемые меннонитам льготы остановят стремление их к выселению из России. Хотя «некоторые продолжают еще твердо держаться принятого ими намерения, то это или крайние фанатики, которые не могут помириться ни с какими льготами, или распродавшие имущества свои еще до обнародования льгот и увлекаемые родственниками их, переселившимися уже в Америку, большинство же переселяющихся принадлежит к разряду безземельных поселян. $<\ldots>$...Из Хортицкой волости, заключающей в себе более 1000 семейств менонитов, выселилось в Америку, из числа владеющих землею только 28 семейств, численностью в 107 муж. и 76 жен. пола, а 188 семейств 816 душ муж. и 706 жен. принадлежат к числу безземельных» [13, л. 9-9 об].

Некоторые из меннонитов стремились выехать на восточные окраины страны, так как в этом случае они освобождались от воинской повинности на 20 лет. Так, в 1879 г. часть молочанских меннонитов Таврической губернии просила разрешения у Туркестанского генерал-губернатора К.П. Кауфмана переселиться в Туркестанский край $[2$, с. 81]. Тот разрешил им переселиться в местность Капланбек. Первая партия меннонитов состояла из 55 семей Таврической губернии, а позже к ним присоединились 3 семьи из Кубанской области и 3 из Самарской губернии [10, c. 485$]$.

Осенью 1879 г. к меннонитам был послан барон фон Унгерн Штернберг с предложением альтернативной службы по призыву в лесных командах. Предполагалось, что каждый год по жребию будут выделяться около 100 рекрутов призывного возраста [9, с. 156]. Кроме того, они должны были принять решение содержать «на свои собственные средства обязанных рабочих... или министерство распределит меннонитов работников мелкими партиями во многие лесничества, причем они будут довольствуемы всем необходимым» $[12$, л. 5].

Меннониты выразили желание служить в лесных командах, потому что эта служба отвечала их религиозным убеждениям и образу жизни, но просили, чтобы «министерство распределило всех меннонитов работников не более как в 6 команд» $[12$, л. 5]. Для согласования условий службы в июне 1880 г. к ним отправили государственного советника П.Л. Барка.

Следует отметить, что российское правительство стремилось извлечь из этой ситуации максимальную выгоду. Поэтому предлагало материальное обеспечение лесных команд возложить целиком на плечи меннонистской общины: оплата стоимости помещения, питания и одежды для них. В течение нескольких лет необходимо было соорудить 6 лагеpей: 2 - в Таврической губернии, 2 - в районе Екатеринослава, 2 - около Херсона. Однако меннониты предложили немного изменить условия.

В предложении говорилось, что в 1880 г. будут сооружены два лагеря в Азове и Великом Анадоле - в лесных станциях севернее Мариуполя (недалеко от меннонитского поселения Бергталь). Рекруты 1881 г. службы отправятся на станции Владимиров и Ратцин возле Херсона (недалеко от меннонитского поселения Заградовка). Еще два лагеря для рекрутов 1882 г. построят в Ново-Бердянске (к югу от поселения Молочна) и где-то в Таврической губернии [9, с. 157].

Точное время появления первой лесной команды и ее численности установить довольно сложно. Существует две точки зрения: 1) $1880 / 81$ г. - на службу отправлено 58 рекрутов для Азова и 15 для Анадола [9, с. 158]; 2) 1881 г. - 123 меннонита призвано на службу (место службы не указано) [27, p. 161].

Меннонитам удалось добиться, чтобы лесные команды подчинялись не военному ведомству, а Лесному департаменту Министерства государственных имуществ ${ }^{1}$. С 1880 по 1907 г. срок службы по Уставу составлял 4 года, а с 1907 г. был сокращен до 1 года. Кроме того, на меннонитов, имевших аттестат о получении образования, распространялись льготы. 
Служили они в качестве обязанных рабочих, а не рядовых, поэтому их труд оплачивался по 20 копеек за каждый отработанный день. Деньги на руки не выдавались, а пересылались уполномоченному. Например, в циркуляре Тобольского управления земледелия и государственных имуществ указывалось: «По окончании каждого календарного, начиная с октября месяца, высылать уполномоченному меннонитских общин Д.И. Классену (Почт. Конт. Гальбштадт, Таврическая губерния) причитающуюся за действительно отработанные дни плату, по указанному выше расчету, т. е. по 20 коп. за день из тех кредитов, в счет которых производились работы при участии меннонитов...» [6, с. 115].

Обязанным рабочим выдавались денежные средства - харчевые и командировочные. Деньги распределялись в зависимости от вида выполненных работ. Если меннонит работал один, то он получал 11 рублей в месяц. Если работа производилась группой из 6 человек, то каждый получал по 10 рублей, а если в группе было больше человек, то каждому меннониту выделялось по 9 рублей [6, с. 116]. Размер средств, необходимых на обмундирование обязанных рабочих, устанавливался на меннонитском съезде и мог варьироваться от 50 до 75 рублей 27 копеек на новобранца - призывника первого года службы. Учет меннонитов, находящихся в запасе, и призыв их из запаса в лесные команды, порядок увольнения в отпуск или вовсе от службы возлагались только на чинов полиции $[21$, л. 12$]$. Раз в год им полагался отпуск длительностью 2 месяца.

Что касается финансового обеспечения лесных команд, то здесь необходимо выделить два источника его формирования: государственное обеспечение и собственные средства меннонитской общины. Государство брало на себя обязательства по оплате: труда обязанных рабочих; найма и коммунальных услуг квартир для рабочих, до истечения одного года после постройки казарм, а также если работы производились вдали от казарм; лечения заболевших; оборудования мастерских по изготовлению и ремонту необходимых орудий и инструментов.

На плечи меннонитской общины ложились следующие обязательства: постройка и оснащение казарм, в которых размещались лесные команды; приобретение обмундирования и продовольствия; доставка меннонитов до места службы; оплата земли, отведенной лесным командам для сельскохозяйственных нужд.

Чтобы выполнить свои обязательства меннонитами было принято решение обложить мужское население колоний в возрасте от 14 до 60 лет особым подушным налогом в размере 50 копеек в год [1, с. 84]. Для этого меннонитские колонии поделили на 28 оценочных округов. С них денежные средства поступали на специальный счет уполномоченного по вопросам лесных команд (№ 438) в Гальбштадте в «Молочанском обществе взаимного кредита». От уплаты лесного сбора освобождались школы, благотворительные и попечительные организации, больницы, церкви и колонисты, недвижимость которых не превышала 500 рублей.

Кроме того, меннонитами были построены 5 казарм на 80 человек каждая в Екатеринославской, Херсонской, Таврической губерниях. Эти постройки обошлись колониям в 35000 рублей [1, с. 85]. В целом на строительство необходимых построек для лесных команд было потрачено приблизительно 160000 рублей [28, p. 9]. По договору 1884 г., заключенному между меннонитами и Департаментом государственных имуществ, все казарменные постройки через 20 лет должны были отойти государственной казне.

За взаимодействие с властями по финансовым вопросам в лесных командах отвечал уполномоченный, которого избирали из наиболее влиятельных членов меннонитских общин Российской империи. Он должен был знать русский язык и разбираться в законодательно-правовых актах страны. Им решались административно-хозяйственные вопросы и материально-техническое обеспечение команд, а также он следил за рациональным использованием денежных средств.

Приоритетным правом выдвижения на эту должность в количестве 3 человек обладали наиболее крупные меннонитские волости: Гальбштадская, Гнаденфельдская, Хортицкая. Уполномоченный защищал интересы обязанных рабочих на уровне региональных и центральных органов власти. За свой труд он полу- 
чал жалованье в размере 1200 рублей в год. Например, в разные годы должность уполномоченного по лесным командам занимали П.П. Ремпель (колония Эйнлаге, Хортицкая волость), Я.Я. Зудерман (колония Анаплее, Мелитопольский уезд), Д. Дик (Гальбштадт), Д.И. Классен (Гальбштадт) [24, л. 10 об].

На ежегодных меннонитских съездах обсуждались вопросы по деятельности лесных команд: отчеты по финансам за прошедший год и формирование бюджета на новый год, отчет уполномоченного о проделанной работе. На них всегда присутствовали депутаты из всех колоний.

Новобранцев-меннонитов призывали на действительную службу и распределяли по лесничествам в октябре - ноябре предшествующего года. Затем их временно распускали по домам до 1 марта следующего года, когда они должны были явиться на место службы [22, л. 2-11].

К 1914 г. насчитывалось 8 меннонитских лесных команд. Они были расположены в Херсонской, Екатеринославской и Таврической губерниях и в Степном крае.

В Херсонской губернии находились следующие команды: 1) Рацынская (Рацынское лесничество Елизаветградского уезда, в 18 верстах от г. Вознесенска); 2) Владимировская (Владимировское лесничество Херсонского уезда, в 15 верстах от станции Николо-Козельск Екатерининской ж. д.); 3) Жеребковская (Жеребковское лесничество Ананьевского уезда, в 4 верстах от станции Жеребковка Юго-Запажной ж. д.); 4) Чернолесская (Чернолесское лесничество Александрийского уезда, в 7 верстах от станции Знаменка Южной ж. д.).

В Екатеринославской губернии расположились команды: 1) Велико-Анадольская (Велико-Анадольское лесничество Мариупольского уезда, в 20 верстах от станции ВеликоАнадоль Екатерининской ж. д.); 2) Азовская (Азовское лесничество, в 10 верстах от г. Мариуполя).

В Таврической губернии находилась Бердянская лесная команда (Старо-Бердянское и Ново-Бердянское лесничества, близ г. Мелитополя). В Степном крае в 1913 г. была создана Иссыль-Кульская лесная команда для меннонитов Сибири. Кроме того, в Крыму работал мобильный филлоксерный отряд, котрый обрабатывал виноградники с целью защиты от вредителей.

О том, что представляли из себя лесничества можно судить на примере Рацынской лесной команды. Лесничество было расположено в сухой местности на участке в 2500 десятин земли. Обязанные рабочие жили в казарме, в которой размещалось 6 палат для рабочих-меннонитов. Кроме того, имелись: столовая (выполнявшая также функцию молельной), кухня, пекарня, комнаты для поваров, хлебопеков и старшего надсмотрщика из числа рабочих. Палаты для рабочих были сухие, светлые, с высокими окнами и потолками; в каждой из них помещалось по 12 рабочих. Больница, аптека и библиотека размещались в отдельном флигеле на дворе. Для обеспечения меннонитов продовольствием и тягловой силой держались конюшня (на 26 лошадей), свинарня (на 40 свиней), коровник (на 18 коров), кузнечная и плотничная мастерская [2, с. 88]. Конечно, не везде были такие хорошие условия. Например, в Старо-Бердянском лесничестве одна из казарм была старая и сырая.

Кормили обязанных рабочих 4 раза в день. Меню обеда и ужина утверждалось ежегодно на меннонитских съездах по делам лесных команд. На завтрак и полдник обычно выдавался хлеб и чай. Следует отметить, что «Роспись кушаньям» (меню) обязательно вывешивалась в кухне каждой казармы. Отступать от нее разрешалось в крайних случаях и только с разрешения эконома [20, л. 88].

Все работы, которые выполняли лесные команды, были связаны с сельскохозяйственным календарем полевых работ. Например, весной высаживались различные породы деревьев, зимой производились чистка и рубка старого леса, но главной обязанностью была охрана леса.

В свободное время они могли заниматься музыкой или читать книги. Для этого существовала библиотека, которая формировалась и пополнялась на средства меннонитских общин. Книги были на русском и преимущественно на немецком языке. В свободное от работы время команда занималась чтением и письмом на русском языке. Занятия велись ежедневно и состояли в чтении на рус- 
ском языке с пересказом прочитанного и письме, причем лучше подготовленные писали под диктовку, более слабые списывали из книг [19, л. 3-6]. Несмотря на пропагандирование христианских ценностей, воспитательной работы среди меннонитов почти не проводилось. Даже наличие проповедника эконома не спасало от пьянства, драк и неуставных отношений [28].

К нарушившим дисциплину рабочим применялись различные меры наказания в зависимости от тяжести проступка - от штрафа до ареста. На основании приложения к ст. 23 Лесного устава от 1905 г. при простом аресте виновные содержались «каждый отдельно, в светлом карцере; пищу получали обыкновенную, но спали на голых нарах. При строгом аресте рабочие так же одиночно содержались в светлом карцере и спали на голых нарах. Им отпускалось ежедневно только хлеб и соль, а горячая пища - через 2 дня на $3 »[17$, л. 39]. Например, 2-недельному строгому аресту был подвергнут обязанный рабочий Генрих Генрихов Реймер, который выдавал себя за больного и уклонялся от работ [20, л. 21].

Бывали случаи, когда служившие меннониты бежали за границу. Так, рацынский лесничий в рапорте от 13 февраля 1903 г. писал: «...обязанный рабочий вверенной ему команды Петр Абрамов Варкентин, призыва 1900 г. из данного ему зимнего отпуска в команду не возвратился, и по сообщению прибывших из отпуска его товарищей бежал за границу. Подтверждается это еще и тем, что от него было получено письмо из Лондона» [22, л. 53].

В целом обязанные рабочие добросовестно выполняли свою работу, и начальство поощряло их за хорошую службу. Например, Томское управление земледелия и государственных имуществ просило наградить меннонита Генриха Унгера нагрудной серебряной медалью на Станиславской ленте за тушение лесных пожаров в Тургайском лесничестве [20, л. 104].

Результаты. Меннониты, переселившиеся в Россию с конца XVIII до середины XIX в., были освобождены от воинской повинности. После проведения военной реформы в 1874 г. они вынуждены были согласиться на альтернативную службу в лесных командах в качестве обязанных рабочих: охранять лес, рас- чищать его от старых деревьев и сажать новые, тушить пожары. Однако им удалось договориться с властями о причислении лесных команд к гражданскому ведомству, а не военному, поэтому их служба регулировалась не Воинским уставом, а Лесным. Кроме того, организация и обеспечение лесных команд легли полностью на плечи меннонитского общества. Благодаря таким послаблениям российскому правительству удалось значительно уменьшить отток меннонитов из страны.

\section{ПРИМЕЧАНИЕ}

${ }^{1}$ В 1894 г. оно будет преобразовано в Министерство земледелия и государственных имуществ, в 1905 г. сменит название на Главное управление землеустройства и земледелия, в 1915 г. станет Министерством земледелия.

\section{СПИСОК ЛИТЕРАТУРЫ}

1. Берестень, Ю. В. Организация и становление альтернативной службы меннонитов в лесничествах царской России во второй половине XIX начале ХХ вв. / Ю. В. Берестень // Вопросы германской истории. - Днепропетровск : Изд-во Днепропетр. ун-та, 2000. - С. 80-99.

2. Бондар, С. Д. Секта меннонитов в России (в связи с историей немецкой колонизации на юге России). Очерк / С. Д. Бондар. - Петроград : Тип. В.Д. Смирнова, 1916. -208 с.

3. Вибе, П. П. Из истории меннонитов в России / П. П. Вибе // Немцы Сибири: история и культура : материалы Всерос. науч.-практ. конф. - Омск : Ом. гос. ист.-краевед. музей, 1993. - С. 41-45.

4. Глушаченков, А. А. Военные реформы в истории России : монография / А. А. Глушаченков, А. В. Чертищев. - М. : Изд-во Воен.-воздуш. инж. акад., 2011. $-504 \mathrm{c}$.

5. Дело о принятии мер к приостановлению стремления меннонитов к эмиграции из России // Российский государственный исторический архив (РГИА). - Ф. 1282. - Оп. 2. - Д.79. - 73 л.

6. Жарова, А. С. Меннониты на службе в лесных командах Курганского уезда Тобольской губернии (конец XIX - начало XX века) / А. С. Жарова // Вестник Челябинского государственного университета. История. Вып. 37. - 2009. - № 38 (176). - С. 114-117.

7. Зайончковский, П. А. Военные реформы 1860-1870 годов в России / П. А. Зайончковский. М. : Изд-во МГУ, 1952. - 371 с. 
8. Игнатенко, В. М. Военные реформы $1862-$ 1874 годов в России / В. М. Игнатенко, Д. Н. Соловьев. - СПб. : СРП «Павел» ВОГ, 2010. - 245 с.

9. Клиппенштейн, Л. Отказ от военной службы по мотивам совести в меннонитских общинах царской России / Л. Клиппенштейн // Долгий путь российского пацифизма : Идеал международного и внутреннего мира в религиозно-философской и общественно-политической мысли России. - М. : ИВИ РАН, 1997. - С. 150-171.

10. Литвинов, П. П. Меннониты в Средней Азии (конец XIX - начало XX в.) / П. П. Литвинов // Государство, общество, церковь в истории России XX-XXI веков. В 2 ч. Ч. 2 : материалы XV Междунар. науч. конф., 23-24 марта 2016 г. - Иваново : Изд-во Иван. гос. ун-та, 2016. - С. 484- 488.

11. Нелипович, С. Г. Военная повинность в России и иностранные колонисты / С. Г. Нелипович // Военно-исторический журнал. - 2003. - № 2. - С. 39-41.

12. Об образовании меннонитской команды в Верхнеднепровском лесничестве Таврической губернии // РГИА. - Ф. 387. - Оп. 13. - Д. 56720. - 29 л.

13. Об отбывании обязательной службы меннонитами // РГИА. - Ф. 1292. - Оп. 1. - Д. 317. 388 л.

14. Об отбывании обязательной службы меннонитами. № 54568 // Полное собрание законов Российской империи (ПСЗ РИ). Собрание второе. T. L. Отделение первое. 1875. - СПб. : Тип. ІІ Отд-ния Собств. Его Императ. Величества Канцелярии, 1877. - C. $340-341$.

15. О введении всеобщей воинской повинности. № 52983 // ПСЗ РИ. Собрание второе. Т. XLIX. Отделение первое. 1874. - СПб. : Тип. II Отд-ния Собств. Его Императ. Величества Канцелярии, 1876. - C. 1-2.

16. О дозволении всем иностранцам, в Россию въезжающим, поселяться в которых Губерниях они пожелают и о дарованных им правах. № 11.880 // ПСЗ РИ. Собрание первое. Т. XVI. 28 июня 1762 1765 гг. - СПб. : Тип. ІІ Отд-ния Собств. Его Императ. Величества Канцелярии, 1830. - С. 313-316.

17. О самовольных отлучках обязанных рабочих меннонитов // РГИА. - Ф. 387. - ОП. 19. Д. $71013 .-82$ л.

18. О стремлении меннонитов к выселению из России // РГИА. - Ф. 1246. - Оп. 1. - Д.14. - 18 л.

19. Отчеты о деятельности меннонитских лесных команд в 1904 г. в Бессарабской, Екатеринославской, Таврической и Херсонской губерний // РГИА. - Ф. 387. - Оп. 9. - Д. 48701. - 134 л.

20. Переписка по делам меннонитских команд // РГИА. - Ф. 387. - Оп. 18. - Д. 68737. - 193 л.

21. По вопросу о порядке перечисления обязанных рабочих из меннонитов в ратники ополчения // РГИА. - Ф. 1292. - Оп. 1. - Д. 791. - 137 л.
22. Послужные списки обязанных рабочих из меннонитов, принятых на службу в призыв 1900 г. // РГИА. - Ф. 387. - Оп. 7. - Д. 41135. - 154 л.

23. Рейнмарус, А. Меннониты (краткий очерк) / А. Рейнмарус, Г. Фризен. - М. : Безбожник, 1930. - $84 \mathrm{c}$.

24. Секретная переписка с Особым комитетом по борьбе с немецким засильем по вопросу о содержании лесных команд // РГИА. - Ф. 387. Оп. 19. - Д. $71028 .-178$ л.

25. Стволыгин, К. В. Отказы от военной службы вследствие убеждений в Российской империи / К. В. Стволыгин. - Минск : РИВШ, 2010. - 248 с.

26. Шульга, И. И. Немцы Поволжья в российских вооруженных силах: воинская служба как фактор формирования патриотического сознания / И. И. Шульга. - М. : Междунар. союз нем. культуры, 2008. - $176 \mathrm{c}$.

27. Brock, P. Freedom from Violence: Sectarian Pacifism from the MiddleAges to the Great War/P. Brock. Toronto : University of Toronto Press, 1991. - $385 \mathrm{p}$.

28. Günter, W. "Onsi Tjedis” Ersatzdienst der Mennoniten in Russland unter der Romanos / W. Günter, D. Heibrecht, H. Peters. - Yarrow : Columbia, 1966. -312 p .

\section{REFERENCES}

1. Beresten Yu.V. Organizatsiya i stanovlenie alternativnoy sluzhby mennonitov $\mathrm{v}$ lesnichestvakh tsarskoy Rossii vo vtoroy polovine XIX - nachale XX vv. [Organization and Formation of Alternative Service of Mennonites in the Forest Areas of Tsarist Russia in the Second Half of the $19^{\text {th }}-$ Early $20^{\text {th }}$ Centuries]. Voprosy germanskoy istorii [The Issues of German History]. Dnepropetrovsk, 2000, pp. 80-99.

2. Bondar S.D. Sekta mennonitov v Rossii (v svyazi s istoriey nemetskoy kolonizatsii na yuge Rossii). Ocherk [The Mennonite Sect in Russia (In Connection with the history of German Colonization in the South of Russia). Essay]. Petrograd, Tipografiya V.D. Smirnova, 1916. 208 p.

3. Vibe P.P. Iz istorii mennonitov v Rossii [From the History of Mennonites in Russia]. Nemtsy Sibiri: istoriya i kultura: materialy vserossiyskoy nauchnoprakticheskoy konferentsii [Germans of Siberia. History and Culture. Materials of the All-Russian Scientific and Practical Conference]. Omsk, Omskiy gosudarstvennyy istoriko-kraevedcheskiy muzey, 1993, pp. 41-45.

4. Glushachenkov A.A., Chertishchev A.V. Voennye reformy $v$ istorii Rossii: monografiya [Military Reforms in the History of Russia: Monograph]. Moscow, Izdatelstvo Voennovozdushnoy inzhenernoy akademii, 2011. 504 p. 
5. Delo o prinyatii mer k priostanovleniyu stremleniya mennonitov k emigratsii iz Rossii [The Case of Taking Measures to Suspend the Desire of Mennonites to Emigrate from Russia]. Rossiyskiy gosudarstvennyy istoricheskiy arkhiv (RGIA) [Russian State Historical Archive], F. 1282, Op. 2, D.79, 731 .

6. Zharova A.S. Mennonity na sluzhbe v lesnykh komandakh Kurganskogo uezda Tobolskoy gubernii (konets XIX - nachalo XX veka) [Mennonites in the Service of Forest Teams in Kurgan Uyezd of Tobolsk Province (Late $19^{\text {th }}$ - Early $20^{\text {th }}$ Century)]. Vestnik Chelyabinskogo gosudarstvennogo universiteta. Istoriya [Bulletin of Chelyabinsk State University.History], 2009, no. 38 (176), iss. 37, pp. 114-117.

7. Zayonchkovskiy P.A. Voennye reformy 1860 1870 godov $v$ Rossii [Military Reforms of 1860-1870 in Russia]. Moscow, Izd-vo MGU, 1952. $371 \mathrm{p}$.

8. Ignatenko V.M., Solovyev D.N. Voennye reformy 1862-1874 godov $v$ Rossii [Military Reforms in 1862-1874 in Russia]. Saint Petersburg, SRP "Pavel" VOG, $2010.245 \mathrm{p}$.

9. Klippenshteyn L. Otkaz ot voennoy sluzhby po motivam sovesti $\mathrm{v}$ mennonitskikh obshchinakh tsarskoy Rossii [Conscientious Objection to Military Service in the Mennonite Communities of Tsarist Russia]. Dolgiy put rossiyskogo patsifizma: Ideal mezhdunarodnogo i vnutrennego mira $v$ religioznofilosofskoy i obshhestvenno-politicheskoy mysli Rossii [The Long way of Russian Pacifism: Ideal of International and Internal Peace in the ReligiousPhilosophical and Socio-Political Thought of Russia]. Moscow, IVI RAN, 1997, pp. 150-171.

10. Litvinov P.P. Mennonity v Sredney Azii (konets $X I X$-nachalo $X X$ v.) [Mennonites in Central Asia (Late $19^{\text {th }}-$ Early $20^{\text {th }}$ c.)]. Gosudarstvo, obshhestvo, tserkov v istorii Rossii XX-XXI vekov. Materialy XV Mezhdunarodnoy nauchnoy konferentsii 23-24 marta 2016 g. [State, Society, Church in the History of Russia of the $20^{\text {th }}-$ $21^{\text {st }}$ Centuries. Proceedings of the $15^{\text {th }}$ International Scientific Conference. March 23-24, 2016]. Ivanovo, Izd-vo Ivanovskogo gosudarstvennogo universiteta, 2016, pp. 484-488.

11. Nelipovich S.G. Voennaya povinnost $v$ Rossii i inostrannye kolonisty [Military Service in Russia and Foreign Colonists]. Voenno-istoricheskiy zhurnal [Military Historical Journal], 2003, no. 2, pp. 39-41.

12. Ob obrazovanii mennonitskoy komandy v Verkhnedneprovskom lesnichestve Tavricheskoy gubernii [About Formation of Mennonite Team in the Verkhnedneprovsky Forestry of the Tauride Province]. RGIA,F. 387, Op. 13, D. 56720, 291.

13. Ob otbyvanii obyazatelnoy sluzhby mennonitami [On Performing Involuntary Service by the Mennonites]. Rossiyskiy gosudarstvennyy istoricheskiy arkhiv (RGIA) [Russian State Historical Archive], F. 1292, Op. 1, D. 317, 3881.

14. Ob otbyvanii obyazatelnoy sluzhby mennonitami. No. 54568 [On Performing Involuntary Service by the Mennonites]. Polnoe sobranie zakonov Rossiyskoy imperii (PSZ RI) [The Full Collection of the Laws of the Russian Empire]. Coll. II, T. L, Otd. I. Saint Petersburg, Tip. II Otd-niia Sobstv. Ego Imperat. Velichestva Kantseliarii, 1877, pp. 340-341.

15. O vvedenii vseobshchey voinskoy povinnosti. No. 52983 [On the Introduction of Universal Military Obligation]. PSZ RI. Coll. T. XLIX, Otd. I. Saint Petersburg, Tip. II Otd-niia Sobstv. Ego Imperat. Velichestva Kantseliarii, 1876, pp. 1-2.

16. O dozvolenii vsem inostrantsam, v Rossiyu vezzhayushchim, poselyatsya v kotorykh Guberniyakh oni pozhelayut i o darovannykh im pravakh. No. 11.880 [About Permission to All Foreigners Entering Russia to Settle in Provinces They Will Wish and About the Rights Granted to Them]. PSZ RI. Coll. 1, T. XVI, 28 June 17621765. Saint Petersburg, Tip. II Otd-niia Sobstv. Ego Imperat. Velichestva Kantseliarii, 1830, pp. 313-316.

17. O samovolnykh otluchkakh obyazannykh rabochikh mennonitov [On Willful Absences of Mennonite Obligated Workers]. Rossiyskiy gosudarstvennyy istoricheskiy arkhiv (RGIA) [Russian State Historical Archive], F. 387, Op. 19, D. 71013, 821.

18. O stremlenii mennonitov $\mathrm{k}$ vyseleniyu iz Rossii [On Striving of the Mennonites to Migration from Russia]. Rossiyskiy gosudarstvennyy istoricheskiy arkhiv (RGIA) [Russian State Historical Archive], F. 1246, Op. 1, D. 14, 181.

19. Otchety o deyatelnosti mennonitskikh lesnykh komand v 1904 g. v Bessarabskoy, Ekaterinoslavskoy, Tavricheskoy i Khersonskoy guberniy [Reports on the Activities of the Mennonite Forest Teams in 1904 in Bessarabia, Ekaterinoslav, Taurida and Kherson Provinces]. Rossiyskiy gosudarstvennyy istoricheskiy arkhiv (RGIA) [Russian State Historical Archive], F. 387, Op. 9, D. 48701, 1341.

20. Perepiska po delam mennonitskikh komand [Correspondence on Affairs of the Mennonite Teams]. Rossiyskiy gosudarstvennyy istoricheskiy arkhiv (RGIA) [Russian State Historical Archive], F. 387, Op. 18, D. 68737, 1931.

21. Po voprosu o poryadke perechisleniya obyazannykh rabochikh iz mennonitov $\mathrm{v}$ ratniki opolcheniya [On the Issue of the Order of Listing Obligated Workers from the Mennonites to the Warriors of the Militia]. Rossiyskiy gosudarstvennyy istoricheskiy arkhiv (RGIA) [Russian State Historical Archive], F. 1292, Op. 1, D. 791,137 1.

22. Posluzhnye spiski obyazannykh rabochikh iz mennonitov, prinyatykh na sluzhbu v prizyv $1900 \mathrm{~g}$. [Military Register of Obliged Workers from the 


\section{ОТЕЧЕСТВЕННАЯ ИСТОРИЯ}

Mennonites Recruited in the Military Service in 1900]. Rossiyskiy gosudarstvennyy istoricheskiy arkhiv (RGIA) [Russian State Historical Archive], F. 387, Op. 7, D. $41135,1541$.

23. Reynmarus A., Frizen G. Mennonity (kratkiy ocherk) [Mennonites (Short Essay)]. Moscow, Bezbozhnik Publ., 1930. 84 p.

24. Sekretnaya perepiska s Osobym komitetom po borbe s nemetskim zasilem po voprosu o soderzhanii lesnykh komand [Secret Correspondence with the Special Committee on the Combat with German Dominance on the Issue of Maintaining Forest Teams]. Rossiyskiy gosudarstvennyy istoricheskiy arkhiv (RGIA) [Russian State Historical Archive], F. 387, Op. 19, D. 71028, 1781.

25. Stvolygin K.V. Otkazy ot voennoy sluzhby vsledstvie ubezhdeniy $v$ Rossiyskoy imperii
[Conscientious Objection to Military Service Due to Beliefs in the Russian Empire]. Minsk, RIVSh, 2010.248 p.

26. Shulga I.I. Nemtsy Povolzhya v rossiyskikh vooruzhennykh silakh: voinskaya sluzhba kak faktor formirovaniya patrioticheskogo soznaniya [Volga Germans in the Russian Armed Forces: Military Service as a Factor of Forming Patriotic Consciousness]. Moscow, Mezhdunarodnyy soyuz nemetskoy kultury, 2008. 176 p.

27. Brock P. Freedom from Violence: Sectarian Pacifism from the Middle Ages to the Great War. Toronto, University of Toronto Press, 1991. 385 p.

28. Günter W., Heibrecht D., Peters H. "Onsi Tjedis" Ersatzdienst der Mennoniten in Russland unter der Romanos. Yarrow, Columbia, 1966. 312 p.

\section{Information about the Author}

Ol'ga V. Erokhina, Doctor of Sciences (History), Associate Professor, Professor of the Department of the History of Russia, Moscow Pedagogical State University, Prosp. Vernadskogo, 88, 119571 Moscow, Russian Federation, ov.erokhina@mpgu.su, http://orcid.org/0000-0001-5158-7110

\section{Информация об авторе}

Ольга Викторовна Ерохина, доктор исторических наук, доцент, профессор кафедры истории России, Московский педагогический государственный университет, просп. Вернадского, 88, 119571 г. Москва, Российская Федерация, ov.erokhina@mpgu.su, https://orcid.org/0000-0001-5158-7110 